\title{
Ornithosis in Somerset. Experience in the South Somerset Clinical Area 1964-71
}

\author{
J. P. ANDERSON \\ M.D., F.R.C.P.E., D.C.H. \\ Musgrove Park Hospital, Taunton, Somerset
}

\section{Summary}

During an 8-year period, seventy patients were found, by complement fixation testing, to have had ornithosis. A clinical analysis was made of forty-seven who fulfilled strict diagnostic criteria; thirty-three had been referred to a chest clinic, fourteen had been hospitalized. A non-specific, febrile, myalgic illness with respiratory symptoms was the usual clinical syndrome; cough was a prominent, often dramatic, symptom. Pulmonary crepitations, variable radiographic changes, and a normal white blood cell count were found to be useful diagnostic features. Ornithosis sometimes masqueraded as major chest disease, and could be debilitating. Careful retrospective interrogation revealed significant bird contacts in the majority of patients. Treatment with a tetracycline was of possible clinical benefit.

IN a previous paper (Anderson \& Bridgwater, 1968) the clinical and epidemiological features of ornithosis were described: the present account extends this survey to span an 8-year period. (The inclusive term ornithosis is used in preference to psittacosisthat form of the disease acquired from psittacine birds.) Table 1 shows the incidence as revealed by routine respiratory virus complement fixation testing (CFT) - a diagnostic service widely used by our hospital and general practitioners to investigate patients with bronchopulmonary infection and unexplained pyrexial illness. The seventy patients listed were diagnosed solely upon a minimum CFT of $1 / 60$.

TABLE 1. Incidence of ornithosis in the South Somerset clinical area as revealed by respiratory virus CFT's(Taunton P.H.L.S., 1964-1971 inclusive)

\begin{tabular}{cccc}
\hline Year & $\begin{array}{c}\text { Subjects } \\
\text { tested }\end{array}$ & $\begin{array}{c}\text { No. with } \\
\text { titre 1/160 }\end{array}$ & $\begin{array}{c}\text { Percent } \\
\text { of total }\end{array}$ \\
\hline 1964 & 306 & 7 & $2 \cdot 3$ \\
1965 & 217 & 24 & $11 \cdot 6$ \\
1966 & 281 & 2 & $0 \cdot 7$ \\
1967 & 234 & 2 & $0 \cdot 9$ \\
1968 & 340 & 7 & $2 \cdot 1$ \\
1969 & 587 & 8 & $1 \cdot 4$ \\
1970 & 498 & 5 & $1 \cdot 0$ \\
1971 & 484 & 15 & $3 \cdot 1$ \\
\hline 8 yrs & 2947 & 70 & $2 \cdot 4$ \\
\hline
\end{tabular}

From these seventy, a personal series of fortyseven patients has been culled who also fulfilled the following criteria: a four-fold rise or fall in their ornithosis CFT's; no anamnestic CFT readings greater than one-quarter the diagnosing figure; current chest radiography; and consultant clinical appraisal. Thirty-three of the patients presented at a chest clinic, usually for 'post-influenzal' surveillance; fourteen were in-patients, ten with bronchopulmonary infections, four with unexplained pyrexia (PUO). Table 2 summarizes the commonest features encountered in the study of these forty-seven patients.

To elaborate, it may be noted that in all but PUO patients cough was a prominent, and in half a dramatic, symptom; this has been the experience of others (Barrett \& Greenberg, 1966; Erooga, 1969). This symptom was accompanied by a propensity to mimic major chest disease: tuberculosis, bronchial carcinoma, pulmonary embolism and bronchiectasis being the author's first diagnoses in some patients. In this connection, the white blood cell count was sometimes (negatively) helpful: an absence of a lymphocytosis excluding pertussis, and the absence of a polymorph leukocytosis excluding bacterial pneumonia.

Table 3 shows the age and sex incidence. The female preponderance has been consistently found in this area, but is not generally a feature of the

TABle 2. Frequent features in forty-seven patients

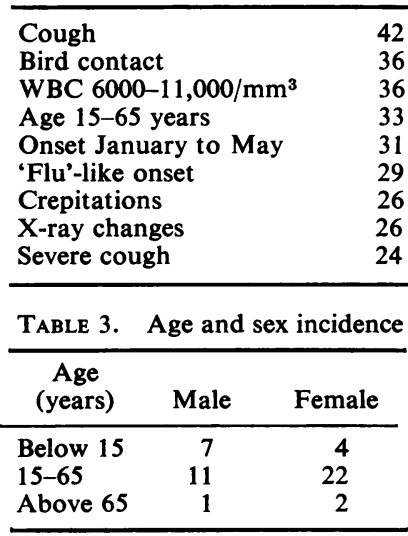


TABLE 4. Month of onset

$\left.\begin{array}{ll}\hline \text { January } & 5 \\ \text { February } & 4 \\ \text { March } & 7 \\ \text { April } & 9 \\ \text { May } & 6\end{array}\right\}$ 31

disease in the country as a whole (British Medical Journal, 1971).

Table 4 shows the seasonal incidence.

Others (Barrett \& Greenberg, 1966; Grist \& McLean, 1964) have also reported more cases in the early months of the year.

A non-specific febrile, myalgic, onset with upper respiratory symptoms was noted in twenty-nine patients.

Auscultation of the chest revealed crepitations in twenty-six patients; this was the only consistently pertinent physical finding.

Radiographic changes were seen in twenty-six subjects: but the extent was not proportional to the severity of the illness, and the kind of shadowing was variable-linear streaking through to frank lobar consolidation being seen. A slow resolution was recorded in several patients and proved an occasional diagnostic hazard.

Since a clinical diagnosis was seldom made, the necessary interrogation of each patient about possible bird contacts was usually retrospective. Table 5 shows the information so gleaned; a positive entry was made only when close contact was clearly recalled. The individual histories elicited were often extremely interesting, and of anecdotal clinical value. One would agree with Grist (1972) that we cannot accept the conclusion (British Medical Journal, 1972) that 'British budgerigars seem rarely to cause human infections'.
TABLE 5. Bird contacts

\begin{tabular}{lr}
\hline Budgerigars & 10 \\
Hens & 6 \\
Pigeons & 5 \\
Wild birds & 4 \\
Finches & 3 \\
Parrots & 3 \\
Pet shop & 2 \\
Turkey & 1 \\
Doves & 1 \\
Owl & 1 \\
None & 11 \\
\hline
\end{tabular}

In none of the patients was the condition lifethreatening, but the fourteen hospitalized were certainly ill. Each of the three patients infected by음 parrots was quite severely affected.

Treatment with a tetracycline had been prescribed before diagnosis in many patients; a therapeutic assessment was therefore impossible-particularly when diagnosis was so often made during convale-io scence. The acutely ill patients to whom tetracyclines were given personally did show clinical benefit.

\section{Acknowledgments}

The author's thanks are due to Dr J. V.S. Pether, Director, P.H.L.S. Taunton, for laboratory reports and to Miss $\frac{c}{2}$ Margaret Gibbons for secretarial help.

\section{References}

ANDERSON, J.P. \& BRIDGWATER, F.A.J. (1968) Ornithosis a chest clinic practice. British Journal of Diseases of the Chest, 62, 155.

BARRETT, P.K.M. \& GReEnBerg, M.J. (1966) Outbreak of ornithosis. British Medical Journal, 2, 206.

EROOGA, M.A. (1969) Some observations on ornithosis. 를 I. The disease in man. In: Some Diseases of Animals Communicable to Man in Britain, p. 143. British Veterinary응 Association, Oxford.

Epidemiology: The Bedsoniae. Public Health Laboratory Service. (1971) British Medical Journal, 2, 539.

Grist, N.R. (1972) Psittacosis. British Medical Journal, 1, 378.

GRIST, N.R. \& MCLEAN, C. (1964) Infections by organisms of: psittacosis-lymphogranuloma venereum group in the west of Scotland. British Medical Journal, 2, 21.

Leading Article (1972) Psittacosis. British Medical Journal, 1,1 . 